\title{
PIIRUSTUKSEN HAURAS VOIMA
}

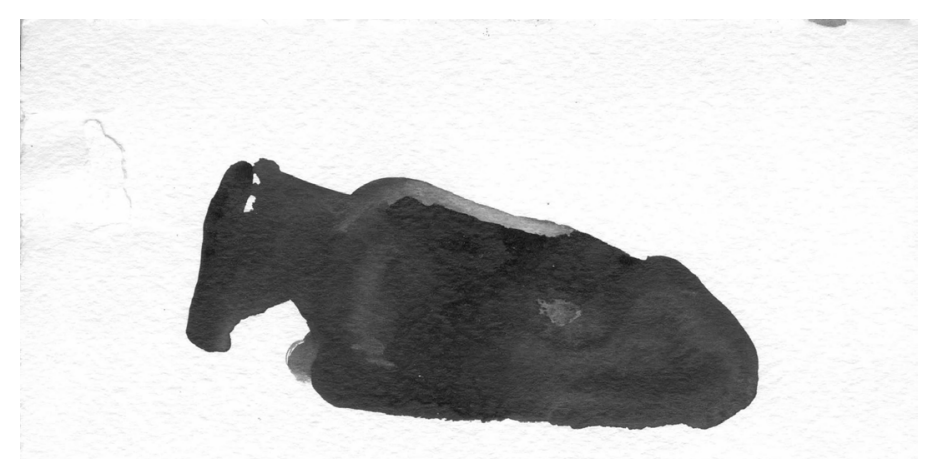

Outi Heiskanen: Lehmä lepää, Goa 1992, tussimaalaus, 12,7 x 19,1 cm.

Ihmisfiguurin ehtymätön rikkaus on taidegraafikko, akateemikko Outi Heiskasen (s. 1937) mielestä hänen tuotantonsa punainen lanka, josta hän on jo vuosikymmenet kehrännyt piirustustensa verkkoa. Ihmiset ovat hänestä aina vain kiinnostavia, jokainen omanlaisensa luonteenpiirteineen, nenineen ja ryppyineen. Heiskanen sanoo olevansa melkein ihmissyöjä; hän sulattaa tapaamiensa henkilöiden kasvot ja olemuksen mahassaan piirustustensa ja vedostensa aineksiksi. "Outi erittää grafiikkaa”, Pentti Kaskipuro on luonnehtinut sattuvasti graafikkokollegaansa. Kuvat näyttävät syntyvän kaiken muun - matkojen, juhlien, tapaamisten ja tapahtumien - ohessa. Taiteilija ei eristäydy työhuoneeseensa. Harvan kalenteri on yhtä täynnä kuin hänen.

Samoin kuin Heiskanen kutoo kuviensa verkkoa, hän tahtomattaankin rakentaa ja sekoittaa ihmisten verkostoa. Hänen ympärillään on aina tilaa taidevammaa poteville, jotka saavat suvaitsevaisen ja rakastavan henkisen kodin. Hänellä on käytössään tai lähellään assistentteja, sukulaisia, eläviä ja kuolleita kollegoja, oppilaita, apumiehiä ja -naisia ja muuta väkeä, jotka kaikki jollain tavalla näyttävät osallistuvan kuvien syntymiseen. Tällainen mehiläiskuningatar hän on.

Heiskasessa on hämmentävää ajattomuutta, vaikka hän ehtimiseen kertoo rakastavansa ajan kulumisen jälkiä ja vanhentumista. "Haluan tulla vanhaksi ja rumaksi", hän sanoo. Olemme tunteneet toisemme yli kolmekymmentä vuotta, ja tapaamisissamme tuntuu olevan mielenkiintoisessa mielessä enemmän samaa kuin erilaista. Myös monet Heiskasen keskeiset kuva-aiheet ja teemat syntyivät jo vuosikymmeniä sitten. Nykyisin taiteilija on isoisoäiti, mutta mummo-sensibiliteetin hän omaksui - traumaattisten kokemusten jälkeen - varhain. Kuten hän on todennut: hän siirtyi suoraan tytöstä mummoksi. Asenne kai vapautti taiteilijan nuoruutta, uutuutta ja nopeutta palvovan kulttuurimme pakoista, antoi niiden sijaan herkkyyttä pois heitetylle, hylätylle, loppuun palaneelle ja kummalliselle. Tästä rakkaudesta kasvaa paljossa hänen piirustustensa hauras voima.

Jos Heiskanen erittääkin kuvia, piirustus ei ole hänelle kuitenkaan liian helppoa, itsestäänselvyys. Olematta maneeri hänen tyylinsä on tunnistettavissa, mutta samalla hänen havainnoissaan ja piirtimen jäljissä on aina tuoreutta ja hapuilevaa nöyryyttä.

Näin Heis kasui kassialmasta akateemikoksi. 